Kovács Éva

\title{
A természeti környezetre utaló településnevek strukturális kérdései*
}

1. A természeti környezetre utaló településneveket — a sajátosságviszonyt kifejező településnevek másik két csoportja, a humán környezetre utaló (pl. személynévi, törzsnévi, népnévi, foglalkozásnévi stb.), valamint az épített környezetre, emberi tevékenységre utaló (pl. lakóépületre, bányákra, vásártartásra stb. utaló) településnevek mellett — a magyar településnév-rendszer fontos névtípusának tarthatjuk. E településnevek a másik két említett kategóriától eltérően az ember tevékenységétől függetlenül is létező helyekkel, entitásokkal állnak összefüggésben. A lokális viszonyra, illetve az általános földrajzi körülményekre utaló településnevek szemantikai és lexikális-morfológiai tekintetben többféle (pl. víznévi, hegynévi, erdőnévi; illetőleg növénynévi, állatnévi stb.) csoportja szoros kapcsolatot mutat a többi névfajtával, így tanulmányozásuk azokra vonatkozóan is fontos adalékokkal szolgálhat. E gyakori és jelentős, de kevésbé kutatott névtípus rendszerbeli helyét, valamint vizsgálatának szükségességét egy korábbi tanulmányomban (2017) fejtettem ki.

Jelen írásomban a természeti környezetre utaló településnevek strukturális típusait vizsgálom, és arra szeretnék rámutatni, hogy az egyes névszerkezeteket milyen szemantikai és lexikális-morfológiai modellek jellemzik, ezeknek milyen gyakorisági mutatóik vannak stb. E téren ugyanis mindezidáig csupán részletkutatásokra támaszkodhatunk (ehhez lásd HOFFMANN-RÁCZ-TóTH 2018: 329-344).

A természeti környezetre utaló településneveknek a vizsgálataimhoz alapul szolgáló korpuszát különböző források, szótárak, adattárak alapján állítottam össze. Közvetlen forrásaim a Korai magyar helynévszótár (KMHsz.) nyomtatásban megjelent 1., valamint szerkesztés alatt lévő 2. és 3. kötete, illetve GYÖRFFY GYÖRGY történeti földrajzi munkája (Gy. 1-4.) és az e munka alapján készült Helynévtörténeti adatok a korai ómagyar korból sorozat kötetei (HA. 1-4.) voltak. Mivel ez a névállomány csak Abaúj-Pilis vármegyék területére korlátozódik, vagyis nem terjed ki a magyar nyelvterület egészére, Pozsega-Zólyom vármegyékre vonatkozóan újabb forrásokat vontam be a vizsgálatba. CSÁNKI DEZSÖ

\footnotetext{
* A tanulmány az MTA-DE Magyar Nyelv- és Névtörténeti Kutatócsoport programja keretében és az NKFI 128270. számú pályázat támogatásával készült.
} 
történeti földrajzi munkája (Cs. 1-5.), illetve a közelmúltban készült, egyes vármegyék helyneveit feldolgozó történeti-etimológiai szótárak, adattárak biztosították a további forrásanyagot. Közülük írásomhoz NÉMETH PÉTER Szabolcs (1997) és Szatmár vármegye (2008) településneveit tartalmazó szótárát, KOCÁN BÉLA Ugocsa vármegyéről készített helynévtörténeti munkáját (2017), valamint KENYHERCZ RÓBERT Szepes vármegyei kéziratos adattárát használtam fel. Ezek mellett egyéb vármegye-monográfiákból is merítettem adatokat és rájuk vonatkozó (elsősorban településtörténeti) ismereteket. Itt említhetjük meg BOROVSZKY SAMU Magyarország vármegyéiről készített monográfiáit (a Pozsony, Somogy, Temes, Torontál, Zemplén és a Vas vármegyei köteteket felhasználva), valamint MÁLYUSZ ELEMÉR Turóc vármegye kialakulásáról (1922/2014) írt munkáját. Az adatokat a korai ómagyar kor végéig (1350-ig) gyüjtöttem össze. Az analízist ilyen módon egy 2193 adatból álló névállományra támaszkodva végeztem el.

2. A tipológiai leírások a helynevek körében három nagyobb szerkezeti típust különítenek el: 1. az egyrészes formáns nélküli neveket, 2. az egyrészes helynévképzővel alakult neveket, illetve 3. az összetétellel alakult kétrészes helyneveket. Az egyes névrészekben szemantikai szempontból sajátosságjelölő (S), fajtajelölö (F) és megnevező (M) funkció fejeződhet ki (vö. HofFMANN 1993: 55). A természeti környezetre utaló településnevek esetében ezek megoszlása a következő arányokat mutatja (1. ábra).

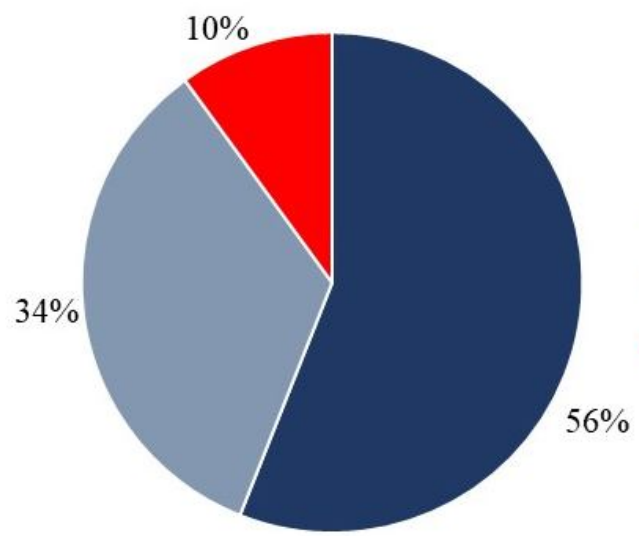

- egyrészes formáns nélküli név - egyrészes képzett név

- kétrészes név

1. ábra. A természeti környezetre utaló településnevek szerkezeti típusai a korai ómagyar korban

A természeti környezetre utaló településnevek névszerkezeti alaptípusai közül a korai ómagyar korban az egyrészes formáns nélküli településnevek teszik ki a névállomány több mint felét (56\%, pl. Kökényér, Szölö stb.), a nevek 34\%-a pedig egyrészes képzett helynévként jött létre (pl. Báránd, Füzi stb.); azaz a névtípus karakterét egyértelműen az egyrészes struktúra határozza meg. A kétrészes természeti környezetre utaló településnevek aránya mindössze 10\% (pl. Szamosfalva, 
Kecskéskér stb.). Hasonló arányokat figyelt meg a HOFFMANN ISTVÁN, RÁCZ ANITA és TÓTH VALÉRIA szerzőhármas egy kisebb névanyagon végzett részkutatás során (2018: 340). Az alábbiakban az egyes névszerkezeti típusokat részletesen is bemutatom.

2.1. A formáns nélküli egyrészes elnevezések lexikális struktúrájukat tekintve négyfélék lehetnek: ezek a névformák ugyanis tartalmazhatnak 1. egyrészes helynevet (pl. Kékes, Tapolca stb.), 2. kétrészes helynevet (pl. Kölesér, Hollókö stb.), 3. földrajzi köznevet (pl. Erdö, Patak stb.) vagy 4. természeti környezetre utaló másfajta köznevet (pl. Komló, Farkas stb.). Ezek megoszlásáról a 2. ábra diagramja tájékoztat.

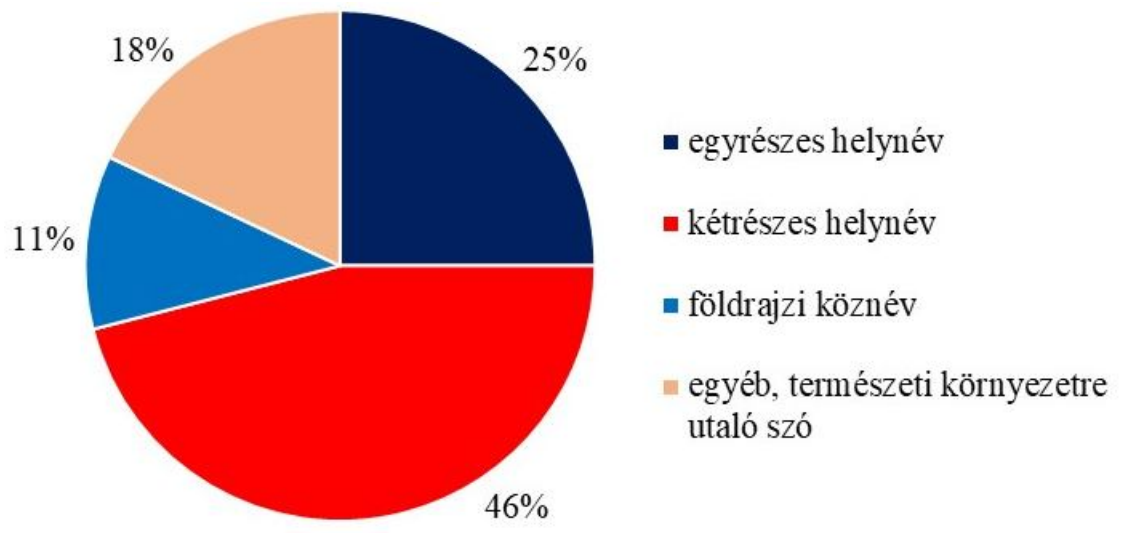

2. ábra. A formáns nélküli egyrészes településnevek típusai az alapszavuk alapján

Az egyrészes formáns nélkül álló településnevek közel három negyed részében biztosan azonosítható helynévi alapszó szerepel (25\%-ban egyrészes, jóval gyakrabban, 46\%-ban pedig kétrészes helynév). Földrajzi köznevek (11\%) és egyéb természeti környezetre utaló lexémák $(18 \%)$ kisebb mértékben vesznek részt e típus településneveinek alkotásában (vö. még HOFFMANN-RÁCZ-TóTH 2018: 335). Meg kell azonban azt is jegyeznünk, hogy helynevek ,a közszói alapszóval azonosítható nevek között is rejtőzhetnek" (i. h.). Az első két esetben a településnevek szemantikai tekintetben lokális viszonyra, a második két esetben pedig általános földrajzi körülményekre utalnak.

2.1.1. A településnév létrejöhet lokális funkciót kifejező, eredetileg nem települést jelölő egyrészes helynévből metonimikus névadással. E névadás alapját döntő többségében víznév szolgáltatta: az esetek 83\%-ában víznévi alapnevet találunk. A mellettük folyó víz nevével azonos nevet viselnek az alábbi települések: Brezova: 1262: Brizona [o: Brizoua], v. (Gy. 4: 361, Nyitra vm.; vö. +1262/[1270 k.]: Brizona [ग: Brizoua], fl., HA. 4: 55), Gölnic: 1286: Guylnech (vö. 1282/1288/1382>1383: Gewlnich, fl., KENYHERCZ é. n., Szepes vm.), Kökényes: 1274: Kukynus (KoCÁN 2017: 91, Ugocsa vm.; vö. 1319: Kukenes, fl., Z. 
1: 164), Lekence: [1285]>1356: Lekenche (KMHsz. 1: 173, Beszterce vidéke; vö. 1356/1357/1358: Lekence, fl., HA. 1: 73), Lipcse: 1263: Lypche, v. (Gy. 4: 69, Liptó vm.; vö. 1265/1270: Lypche, fl., HA. 4: 26), Lipnik: 1330/1449: Lupnyk, v. (vö. 1286/XIX.: Lipnik, aqua, KENYHERCZ é. n., Szepes vm.), Liszkó: 1260: Lysco, t. (vö. 1260: Lysco, aqua, Cs. 3: 79, Zala vm.), Szuha: 1251>1368: Zvha, t. (Gy. 2: 554, Gömör vm.; vö. 1294: in valle Zuha, HA. 2: 69), Tepla: 1264/1696: Tepla, t. (Gy. 4:103, Liptó vm., vö. 1264/1696: Tepla, fl., HA. 4: 28), Vág: 109395: Wag (Gy. 4: 456, Nyitra vm.; vö. 1217 k.: Wag, flum., HA. 4: 66), Veléte: 1280: Veléthe (KOCÁN 2017: 91, Ugocsa vm., vö. 1324/1326/1478: Welethe, fl., AOklt. 8: 241) stb.

Kiemelkedések neveiből is alakulhattak egyrészes településnevek mindenféle formáns hozzáadása nélkül. Az e névszerkezeti típusba tartozó nevek csupán 8\%-a jött létre ily módon: pl. Kékes: 1301: Kekus, v. (Gy. 4: 700, Pilis vm.; vö. 1291>[1520 k.]: Kekes, HA. 4: 76), Rudna: 1290: Rudna (vö. 1272/1272/1315: Ruda, mo., KenYHERCZ é. n., Szepes vm.), Somlyó: 1255: Svmlu (Gy. 3: 493, Krassó vm.; vö. [1292]: Sumlu, HA. 3: 72) Vértes: 1226 PR.: Wertus (Gy. 2: 415, Fejér vm.; vö. *1086: Uertis, HA. 2: 54) stb. Még kisebb számban (7\%) erdö, mező vagy völgy neve szolgált az egyrészes településnév alapjául: pl. Gyepes: 1319: Gepus, p. (vö. 1212: Gepus, s., Cs. 2: 232, Veszprém vm.), Katony: 1340: Katun, p. (vö. 1274/1275/1280/1314/1330/1598: Katthun, vall., KENYHERCZ é. n., Szepes vm.), Zaheus: 1341: Zahyus, p., (A. 4: 561, Pest vm.; vö. 1337/XV.: Zahyws, vall., HA. 4: 73) ${ }^{1}$ stb.

2.1.2. Az összetett lexikális szerkezetü helyneveket tartalmazó településnevek lexikális szempontból két tagból állnak ugyan (egy sajátosságjelölő első névrészből és egy helyfajtajelölő második névrészből), településnévként azonban bennük egyetlen szemantikai jegy fejeződik ki, az tudniillik, hogy a település 'egy bizonyos vízfolyás, kiemelkedés stb. mellett fekszik'. Településnévként e névformák tehát egyrészesnek tekintendők. Az ide tartozó településnevek természeti névi (pl. víznévi, hegynévi, erdőnévi) előzményei nem minden esetben adatolhatók. Ez egyrészt az adatolásbeli hiánnyal magyarázható, másrészt pedig elképzelhetö, hogy az adott mikrotoponima valóban nem létezett. Egy korábbi írásomban (KOVÁCS É. 2017) a halom névelemet tartalmazó településneveket vizsgálva arra a megállapításra jutottam, hogy az első ilyen szerkezetü településnevek minden bizonnyal valamely azonos struktúrájú mikrotoponimából keletkeztek metonimikus névadással. A további ilyen struktúrájú névalakulatok ugyanakkor már nemcsak ilyen módon (tehát közvetlenül mikrotoponimából), hanem a meglévők mintájára, azok névmodelljét követve is létrejöhettek. Másként fogalmazva ez tehát azt

\footnotetext{
${ }^{1}$ Ez utóbbi két név csak akkor tartozik ide, ha a Katony és a Zaheus említések mögött ténylegesen is völgyek nevei rejtőznek, ahogyan erre az oklevél szövege utal.
} 
jelenti, hogy az olyan településeket, amelyek kisebb kiemelkedések mellett feküdtek, valamilyen sajátosságot jelölő előtag + halom földrajzi köznévi utótag szerkezetủ névvel láthatták el a névadó közösség tagjai (vö. pl. az újabb korból: 1927: Bodroghalom, FNESz. stb.). Ezt a jelenséget a szakirodalom más típusú neveknél is felismerte. TÓTH VALÉRIA például a fö 'forrás' utótagú településneveket elemezve jutott arra a következtetésre, hogy a fó 'egy adott vízfolyás forrásánál (vagy annak közelében) lévő település' jelentésben településnév-formánssá vált (2008: 182-187).

Alapnévként az ide vonható településnevek többségében (35\%) víznév (folyóvagy állóvíz neve) szerepel. A következő településnevekben $\mathrm{S}+\mathrm{F}$ szerkezetű kétrészes vízneveket találunk: Kölesér: 1138/1329: Kuleser, v. (KMHsz. 1: 163, Bihar vm.); Feketepatak: 1260: Feketepotok (KoCÁN 2017: 91, Ugocsa vm.), Lassúpatak: 1344: Lassyupatak (KENYHERCZ é. n., Szepes vm.), Szuhapatak: 1324: Swhapathok (Cs. 4: 191, Trencsén vm.); Fehértó: 1220/1550: Fehekton, v., 1326/1326: Feyrtou, p. (NÉMETH 1997: 74, Szabolcs vm.), Füzestó: 1323/1367: Fizestou, p. (Gy. 3: 483, Krassó vm.), Halastó: 1236: Holostov (Cs. 2: 753, Vas vm.), Verestó: 1276: Veristo (Cs. 2: 260, Veszprém vm.); Zsitvatö: 1271/1360/ 1361>1496: Sythwathew, p. (Gy. 3: 464, Komárom vm.); Hidegviz: 1296/1413: Hydegvyz (Gy. 2: 198, erdélyi Fehér vm.) stb.

Sajátos víznévfajtával, források, kutak neveivel hozható kapcsolatba a településnevek 15\%-a: pl. Borfö: 1245: Burfeu (Gy. 3: 180, Hont vm.), Hodosfö: 1331: Hudusfeu (Cs. 2: 756, Vas vm.), Kútfö: 1312/XVIII.: Kuthfeu, p. (KMHsz. 1: 169, Bihar vm.), Nádfö: 1327: Nadfeu, p. (Cs. 3: 443, Tolna vm.), Sárfö: 1185/1249/ 1352: Sarfew, pr. (Gy. 4: 454, Nyitra vm.); Hidegkút: 1289: Hydegkuth (Gy. 3: 292, Esztergom vm.), Szélkút Szilkút: 1332-6/PR.: Zilkuich Zilkuch (Gy. 2: 185, erdélyi Fehér vm.) stb.

A településnevek 13\%-ában kiemelkedések nevei, 9\%-ában pedig erdők nevei találhatók. Az előbbire említhetjük például a Héhalom: 1300/1347: Heeuholm, p. $\sim$ Heuholm, p. (Gy. 4: 250, Nógrád vm.); Feketehegy: 1272/1331: Fekethehygh, castr. (KMHsz. 1: 98, Brassó vm.); Baglyaskő: 1327: Bogloskv, p., t. (Gy. 4: 227, Nógrád vm.), Divénykö: 1275: Dyvenkuy (Gy. 4: 392, Nyitra vm.), Oroszlánkö: 1348: Orozlankw (Cs. 4: 74, Trencsén vm.) stb. településneveket. Az utóbbi csoporthoz pedig az Apátfája: 1347: Apathfaya, p. (NÉMETH 1997: 23, Szabolcs vm.), Borsaharaszta: 1315/369: Borsaharazta, v. (Gy. 2: 62, Doboka vm.), Feketeerdö: [1274 k.]: Fekete Erdeu (Gy. 4: 147, Moson vm.), Monyorókerék: 1221: Monyorokerek (Cs. 2: 717, Vas vm.) stb. településnevek sorolhatók. Ugyancsak 9\%-os arányban vesznek részt a településnév-alkotásban a mezők, rétek, völgyek összetett nevei: pl. Cserepesmezö: 1337: Cheripesmezeu (NÉMETH 2008: 50, Szatmár vm.), Kékmezö: 1342: Keykmezew (Cs. 1: 352, Zemplén vm.), Nyirmezö: 1330: Nyrmezew (Gy. 2: 176, erdélyi Fehér vm.); Bábaréte: 1321: 
Babarethe, p. (KeNYHERCZ é. n., Szepes vm.), Hosszúrét: 1339: Huzyureth, p. (A. 3: 535, Gömör vm.); Füzvölgy: 1332: Fyuzwelg, t. (Cs. 2: 748: Vas vm.), Rekettyésvölgye: 1307: Reketyasuelge, p. (Gy. 2: 202, erdélyi Fehér vm.); Fancsalfenyérje: 1067/1267: Fonsol fenerie, pr. (KovÁCs É. 2018: 45-46, vö. fenyér 'vizes, füves terület'), Piliskefenyérd (1318: Piliskefenerd, p., Cs. 3: 23, Zala vm.) stb. A települések megnevezéseiben szórványosan más struktúrák is előfordulnak ugyan (pl. Árokalja: [1235-70]: Arukalia, p., Gy. 2: 59, Doboka vm.; Csomaköz: 1298/1320: Chamakuz, p., NÉMETH 2008: 51-52, Szatmár vm.; Farkastorok: 1337: Farkasturuk, Cs. 2: 308, Valkó vm.; Macskaszarm: [1249-60]: Machkazorm, t., KMHsz. 1: 178, Bars vm.; Selyemsziget: 1349: Selyemzyketh, Selyemzygeth, p., Cs. 2: 639, Somogy vm.; Verespart: 1322: Wrusporth, p., v., KMHsz. 1: 299, Csanád vm. stb.), ezek azonban — kis számuk, illetve olykor bizonytalan azonosíthatóságuk miatt — részletesebb kifejtést nem igényelnek.

2.1.3. A formáns nélküli egyrészes településnevek harmadik csoportjában olyan helynevek szerepelnek, amelyekben alapszóként nem településnév-formánsként használatos földrajzi köznevek (pl. falu, telek) állnak. A vizsgált névállomány 11\%-át kitevő csoportban jellemzően a vizet, kiemelkedést és erdőt jelentő földrajzi köznevekből alakult településneveket találjuk meg: pl. Arok: 1301: Aruk, p. (Gy. 3: 67, Heves vm.), Eresztvény: 1298: Ereztuen, v. (Cs. 2: 308, Valkó vm.), Erdö: [1270-72]: Erdeu, v. (Gy. 4: 201, Nagysziget), Halom: 1323/1324: Holm (Gy. 4: 520, Pest vm.), Patak: 1230: Potahc, t. (Cs. 3: 623, Sopron vm.), Sár: 1322: Saar (Gy. 4: 454, Nyitra vm.) stb. Más helyfajtára ritkábban történik utalás: pl. Föveny: 1192/1374/1425: Fuen (Gy. 2: 385, Fejér vm.), Mezö: [1291-94]: Mezeu, v. (KMHsz. 1: 186, Bihar vm.), Liget: 1310: Lygeth, t. (Cs. 3: 439, Tolna vm.), Pázsit: 1319: Pasit, p. (KoCÁn 2017: 88, Ugocsa vm.), Rét: 1342/1343: Reth (KENYHERCZ é. n., Szepes vm.).

Ezek a településnevek azonban — noha alapvetően általános földrajzi viszonyokra utalnak - az átmenetiség jegyeit viselik magukon. Elöfordulhat ugyanis az, hogy az adott közszóból természeti név alakul (vö. pl. 1255: Potok, flum., HA. 4: 49, Nógrád vm.), amely metonimikusan településnévvé válik (1255: Potok, v., Gy. 4: 49, Nógrád vm.), s a településnévben ezáltal lokális viszony fejeződik ki, strukturálisan pedig a helynevet (egyrészes helynevet; vö. 1. típus) tartalmazó településnevek között veendő számításba. Minthogy azonban az előzményként feltételezhető mikrotoponima sok esetben nem adatolható a település környezetéböl, annak felderítése, hogy a közszói alapszóval azonosítható településnevek között melyek azok, amelyek lokális viszonyra utalnak, s helynevet tartalmaznak, adatok hiányában nem könnyü (gyakran nem is megoldható) feladat. Az ilyen esetekben ráadásul még azt is figyelembe kell vennünk, hogy a földrajzi köznévvel azonos alakú mikrotoponimák esetében azt sem könnyủ eldönteni, tulajdonnévi vagy köznévi előfordulással van-e dolgunk (vö. RESZEGI 2009). 
2.1.4. A természeti környezetre utaló, de nem földrajzi köznévi lexémákból alakult településnevek a vizsgált elnevezések között 18\%-os arányban tünnek fel. Ezekre a településnevekre szintén az átmenetiség jellemző. Egy Tölgy nevü település (vö. pl. 1264/1393/1466: Thulgh, v., Csongrád vm., KMHsz. 1: 282) esetében például csak további információk birtokában (pl. az oklevél szövege, a birtokleírás, a mikronévi adatok alapján) tudjuk egyértelmúen meghatározni, hogy a településnév-adást a tölgyfákban gazdag környezet motiválta-e (ebben az esetben a településnév általános földrajzi viszonyra utal), vagy pedig a település egy közelben lévő Tölgy nevü erdőről kapta a nevét (s ekkor lokális viszony tükröződik benne). Az itt számba vehető településnevek körében leggyakrabban a növényés állatnévvel azonos alakú településnevek fordulnak elö. Növénynévi alapszó szerepel az Árpa: 1268/1347: Arpa, v. (Gy. 3: 404, Komárom vm.), Berkenye: 1299/1411/1413: Berekenye, t. (Gy. 4: 231, Nógrád vm.), Borostyán: 1282: Burstian, t. (Cs. 2: 401, Pozsega vm.), Gomba: 1301: Gomba (BOROvsZKY, Pozsony, 68), Körtvély: 1208/1359: Kurtuel Kurthuel, v. (Gy. 4: 155, Moson vm.), Mogyoró: 1319: Monorou, p. (Cs. 5: 721, Torda vm.), Nyir: 1249: Nyvr, t. (Gy. 2: 303, Esztergom vm.), Som: 1214/1550: Sum, v. (NÉMETH é. n., Szabolcs vm.) stb. településnevekben; állatnévi lexémát találunk a következö helynevekben: Agár: 1332-37 P.: Agar (Cs. 1: 340, Zemplén vm.), Bika: 1305: Bika, p. (Cs. 3: 418, Tolna vm.), Sas: 1348: Sas (Cs. 1: 670, Külső-Szolnok vm.), Szarka: 1310: Zarka, t. (Cs. 5: 731, Torda vm.) stb. A néva dásban a természeti környezetre utaló egyéb közszó ritkán fordul elő, de lásd pl. Arany: 1333: Aran (Gy. 3: 289, Hunyad vm.), Kö: 1323: Kev (KMHsz. 1: 162, Arad vm.), Só: 1243/1344: Sow, t. (Gy. 2: 87, Doboka vm.), Töke: 1383/1550/1573: Theuke, v. (Gy. 2: 639, Györ vm.); Kék: 1323/1333: Keek, p., t. (NÉMETH 1997: 105, Szabolcs vm) stb.

2.2. A természeti környezetre utaló településnevek második nagy szerkezeti típusához, az egyrészes képzett helynevekhez sorolható elnevezések alapvetően kétféle lexikális alkategóriába tartoznak. A helynévképző egyrészt földrajzi köznévi alapszóhoz, másrészt természeti környezetre utaló közszóhoz járulhat. ${ }^{2}$ A két típus gyakorisága között azonban jelentős eltérés figyelhető meg: az egyrészes képzett településnevek döntő többségében, 86\%-ában a helynévképző természeti környezetre utaló lexémákhoz kapcsolódik, míg a földrajzi köznév + helynévképző szerkezetü településnevek csak 14\%-ot tesznek ki. Mindkét alkategória településneveire a kettős arculat, a fent említett átmenetiség jellemző, vagyis számolni kell esetükben azzal a lehetőséggel is, hogy az általános földrajzi viszonyokat tükröző közszavak előbb maguk is helynevekké, természeti nevekké (víznevekké, hegynevekké stb.) alakulhattak, s ezek szolgáltak aztán a településnevekhez

\footnotetext{
${ }^{2}$ Természetesen a földrajzi köznevek is beletartoznak a természeti környezetre utaló szavak körébe, a modell csak azért tesz efféle különbséget, és emeli ki ezt a szócsoportot, mert annak a helynevekben meghatározó szerepe van.
} 
alapul, immáron lokális viszonyt kifejezve. Ha azonban ezek a „közvetítő” névformák (tehát a víznevek, hegynevek stb.) adatokkal nem igazolhatók, akkor a Kékes, Körtvélyes típusú településnevek ilyen alakulásmódját és szemantikai jellegét sem támogathatjuk meg.

Az ilyen településnevekben többféle képzővel is találkozhatunk mindkét lexikális alcsoport elemei között.

Az -s képzőt tartalmazó, földrajzi köznévi alapszóval álló településnevek között említhetjük például az Árkos: 1330: Arkus (Gy. 2: 131, erdélyi Fehér vm.), Berkes: 1334: Berkus (Cs. 2: 593, Somogy vm.), Erdös: 1243/1335: Erdes, p. (Gy. 2: 482, Gömör vm.), Fövenyes: 1332-37 P.: Feuenyes, Feuenies (Cs. 1: 731, Zaránd vm.), Halmos: 1343: Helmus (BorovszKy, Pozsony, 69), Mocsaras: 1334: Mocharus, t. (Gy. 2: 517, Gömör vm.) stb. névformákat. Természeti környezetre utaló lexéma (főképpen növénynév, állatnév) szerepel viszont pl. a Bodzás: 1242: Bozzas (BOROvSZKY, Zemplén, 31), Diós: 1283/1414/1568: Gyos, p (Gy. 3: 346, Kolozs vm.), Egres: 1245: Egrus, v. (Gy. 4: 516, Pest vm.), Füzes: 1296>1413: Fyzes, p. (Gy. 3: 94, Heves vm.), Gombás: 1300/1325: Gumbas (Gy. 2: 290, Esztergom vm.), Hagymás: +1262/[XIV.]: Hagmas (Gy. 3: 553, Küküllő vm.), Harasztos: 1319/1320: Haraztus, p., v. (Gy. 3: 350, Kolozs vm.), Körtvélyes: 1272: Kvrtelus, t. (KeNYHERCZ é. n., Szepes vm.), Mogyorós: 1295: Monorous, p. (Cs. 2: 777, Vas vm.); Bárányos: 1292: Baranus, p. (NÉMETH 1997: 33, Szabolcs vm.), Disznós: 1312/1427: Dysnos, t. (Gy. 3: 191, Hont vm.) stb. településnevekben.

A - $d$ képzőt tartalmazzák az Érd: +1263/1324/1580: Eerd, p. (Gy. 3: 374, Kolozs vm.), Erdőd: 1316: Erdeud, p. (NÉMETH 1997: 71, Szabolcs vm.), Fertöd: 1234: Ferteud, v. (Cs. 3: 608, Sopron vm.), Halmod: 1291: Holmod, t. (Gy. 2: 387, Fejér vm.), Mocsárd: 1264: Machard, t. (Gy. 4: 423, Nyitra vm.), Sárd: 1238/1296-1301: Sard, v. (Gy. 2: 183, erdélyi Fehér vm.) stb. földrajzi köznévi; illetve az Almád: 1249: Almad (Cs. 3: 18, Zala vm.), Komlód: 1337: Kumlod (NÉMETH 2008: 152, Szatmár vm.), Mogyoród: 1341: Monoyrod, p. Monorod, p. (Gy. 3: 517, Kraszna vm.), Báránd: 1266: Barand, v. (Cs. 3: 416, Tolna vm.), Farkasd: 1326>1351: Farkasd, v. (Gy. 4: 516, Pest vm.), Ökörd: 1259: Vkurd, t. (Gy. 4: 535, Pest vm.), Szamárd: 1292: Zamard, t. (Gy. 2: 275, Esztergom vm.) stb. természeti környezetre utaló egyéb lexémára épülő településnevek.

Az -i képzőt találjuk az Árki: +1086 [1250 k.]: Arqui, pr. (Gy. 2: 346, Fejér vm.), Halmi: 1215/1805: Halmy (KoCÁn 2017: 91, Ugocsa vm.), Homoki: 1274 : Humuky, pr. (Cs. 3: 611, Sopron vm.), Horhi: 12[9]5/1330/1744: Horhi (vö. horha, horhó 'vízmosás', Gy. 3: 203, Hont vm.), Réti: 1210: Rethi, t. (Gy. 2: 621, Györ. vm.); illetve a Füzi: +1262/[XIV.]: Fizy Fyzy, p. (KMHsz. 1: 107, Abaúj vm.), Haraszti: 1348: Harazty, p. (Cs. 3: 233, Veszprém vm.), Nyíri: 1322: Nyry (KoCÁn 2017: 93, Ugocsa vm.), Somi: 1270/1272/1476: Sumy, t. (KMHsz. 1: 243, Bereg vm.), Szili: 1213/1550: Scili (NÉMETH 1997: 182, Szabolcs vm.); Kövi: 
1251: Kuuy (Gy. 2: 297, Esztergom vm.), Méhi: 1332/1549: Mehy (Gy. 2: 525, Gömör vm.) stb. településnevekben.

A közszói alapszóhoz -gy képző kapcsolódik a következö településnevekben: Debregy: 1255: Debregy (vö. debre 'völgy', KMHsz. 1: 81, Abaúj vm.); illetve Almágy: 1275/1410: Almag (Gy. 2: 481, Gömör vm.), Egregy: 1302>1419: Egreh, p., t. (Gy. 2: 360, Fejér vm.), Füzegy: 1338: Fygyz, p. (Gy. 3: 316, Keve vm.), Hásságy: 1328: Hassaagh, v. (Cs. 3: 59, Zala vm.), Kórógy: 1334: Coroug $\sim$ Koroug, p. (Gy. 3: 360, Kolozs vm.), Nyárágy: 1270: Narag (KMHsz. 1: 202, Baranya vm.), Nyüvegy: *1208/1550: Neueg, v. (KMHsz. 1: 204, Bihar vm.), 1261: Neueg (Cs. 1: 741, Zaránd vm.) stb.

Az -sd ( -st) képzőbokor szintén megfigyelhető jó néhány településnévben: földrajzi köznévi lexémához kapcsolódik pl. az Árkosd: 1299: Arcusd (NÉMETH 1997: 25, Szabolcs vm.), Sárosd: 1342: Sarusd (Gy. 2: 402, Fejér vm.) nevekben; jóval gyakrabban látjuk viszont növénynévi és anyagnévi lexémához járulva: pl. Egresd: 1234: Egrest, v. (Cs. 4: 116, Trencsén vm.), Füzesd: 1256: Fyzeth (KMHsz. 1: 107, Baranya vm.), Mogyorósd: 1292/1358//1406>1411: Monyorosd (KMHsz. 1: 190, Borsod vm.), valamint a sokfelé előforduló Nádasd: 1270/1369: Nadasd, p. (KMHsz. 1: 194, Abaúj vm.), +1247/+1284//1572: Nadasd, v. (KMHsz. 1: 194, Arad vm.), 1321: Nadasd, p. (Gy. 3: 297, Hunyad vm.), +1263/1324/1580: Nadasd, p. (Gy. 3: 365, Kolozs vm.), 1258: Nadosth, t., v. (KeNYHERCZ é. n., Szepes vm.), 1233: Nadasth (Cs. 3: 410, Tolna vm.), 1246: Nadasd (Cs. 2: 778, Vas vm.) és Kövesd: 1320: Kuesd, v. (Gy. 2: 297, Esztergom vm.), 1323: Kwesd, t. (Gy. 2: 518, Gömör vm.), 1324>1361: Kwesd (Gy. 2: 606, Györ vm.), 1321/1323/1335: Kwesd, p. (Gy. 3: 110, Heves vm.), 1307/XVII.: Kövesd, t. (Gy. 3: 217, Hont vm.), 1331: Kuesd (Gy. 3: 487, Krassó vm.), 1298/1466: Kuesd, t. (Gy. 4: 262, Nógrád vm.), 1326: Kwesd, t. (Cs. 3: 616, Sopron vm.,) 1093: villa Cuesd et alia villa Cuesd iuxta Sopok (Cs. 3: 74, Zala vm.), 1283: Kuezd (Cs. 1: 337, Zemplén vm.).

A -j képző csupán néhány földrajzi köznévi alapszóhoz kapcsolódva tủnik fel a névállományban: Debrej: 1113: Debrei (DHA. 1: 393, Nyitra vm.), Erdej: [1077-95]/+1158//PR.: Erdey, (Gy. 3: 115, Heves vm.), Halmaj: 1234/1243: Holmoy, t. (Gy. 3: 98, Heves vm.), az -ny képző pedig ugyancsak szórványosan, természeti környezetre utaló lexémával együtt jelentkezik: Harsány: 1267: Horsan, t. (KMHsz. 1: 124, Bács vm.), 1220/1550: Harsan (KMHsz. 1: 124, Bihar vm.), 1239/1465: Harsan, t. (Gy. 3: 421, Komárom vm.), Sásony: 1217: Sasun, v. (Gy. 4: 176, Moson vm.).

Ugyanahhoz az alapszóhoz többféle képző is kapcsolódhat. Ezt láttuk például a fent említett (halom >) Halmos, Halmod, Halmi, Halmaj, (árok >) Árkos, Árkosd, Árki, illetve az (éger >) Egres, Egresd, Egregy, (füz >) Füzes, Füzesd, Füzegy, Füzi, (mogyoró >) Mogyorós, Mogyoród, Mogyorósd stb. településnevek esetében. 
A fenti kategorizáció kapcsán arra is feltétlenül utalnunk kell azonban, hogy a természeti környezetre utaló lexémák (föként az állat- és ritkábban a növénynevek) alapalakban és képzős származékukban személynévként is előfordulnak az Árpád-korban; vö. pl. Bárány: 1212: Baran szn. (ÁSz. 90), Csóka: 1211: Choucha szn. (ÁSz. 200), Farkas: 1138/1329: Farcas Farkas szn. (ÁSz. 300), Farkasd: 1138/1329: Farcasti szn. (ÁSz. 301), Medve: 1138/1329: Medue szn. (ÁSz. 533), Rigó: 1211: Rigou szn. (ÁSz. 676), Tőke: 1138/1329: Tuke szn. (ÁSz. 765766) stb. Ez pedig azt jelenti, hogy az itt tárgyalt településnevek között olyanok is lehetnek, amelyek nem a természeti, hanem a humán környezetre utalnak és birtoklást fejeznek ki.

A képzővel álló egyrészes településneveknek egy további csoportját is megkülönböztethetjük. A helynévképző szórványosan ugyanis kapcsolódhat két névrészből álló természeti névhez, esetleg közszói jelzős szerkezethez is, így alkotva településnevet (HOFFMANN-RÁCZ-TÓTH 2018: 337-338). A Kárpát-medencében sokfelé szép számban előforduló Nagy-árok (pl. 1192/1374/1425: Nogaroc, HA. 1: 40, Bács vm.) mikrotoponimából - $i$ képzővel minden akadály nélkül alakult a Nagyárki (1337 P/PR: Nodyarki, KMHsz. 1: 195, Bodrog vm.) településnév. Ugyanakkor az is előfordulhat, hogy egy (adatokkal nem igazolható) Árki településnévből jelzői névrésszel kiegészülve jött létre a Nagyárki településnév. A vizsgált névkorpuszban erre az alkategóriára további példákat nem találtam.

2.3. A természeti környezetre utaló településnevek harmadik fő szerkezeti típusát a kétrészes településnevek adják.

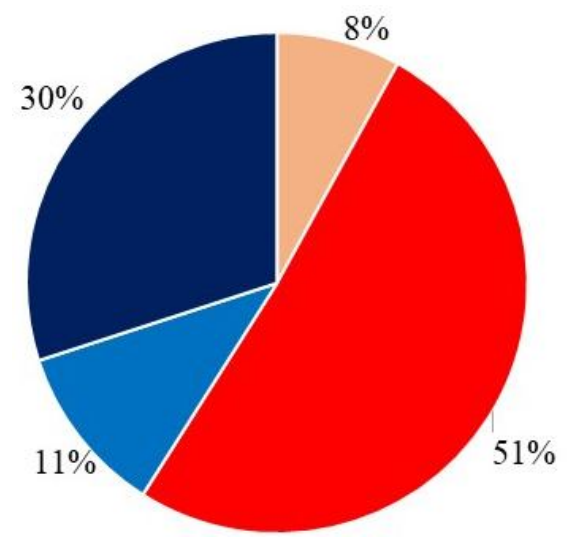

- természeti név + földrajzi köznév

- természeti környezetre utaló szó + földrajzi köznév

- természeti név + településnév

- természeti környezetre utaló szó + településnév

3. ábra. A kétrészes településnevek típusai a korai ómagyar korban

A kétrészes településnevek első névrésze tartalmazhat egyrészt természeti nevet (víznevet, hegynevet stb.), másrészt természeti környezetre utaló köznevet (földrajzi köznevet vagy más típusú lexémát, pl. növénynevet, állatnevet stb.), második névrészükként pedig vagy 'település' jelentésủ földrajzi köznév, vagy településnév áll. Ilyen szerkezetü településnevek azonban a korai ómagyar korban 
meglehetősen ritkán fordulnak elő, a teljes általam vizsgált névállománynak mindössze a 10\%-át teszik ki (lásd az 1 . ábrát), és több mint a felük (59\%-uk) elsődleges településnévként (azaz földrajzi köznévi utótaggal), 41\%-uk pedig másodlagos névként (azaz helynévi utótaggal) jött létre. (Lásd a 3. ábrán.)

2.3.1. Elsődleges településnévként azokkal a településnevekkel számolhatunk, amelyek második névrésze 'település' jelentésü földrajzi köznevet tartalmaz, az előtag pedig a településnek valamilyen földrajzi jellemzőjét (lokális vagy általános földrajzi viszonyát) fejezi ki.

Lokális viszonyra, valamely más típusú hely melletti elhelyezkedésre utalnak a következő helynévi előtagú településnevek: elsősorban víz melletti közelséget tükröznek: vö. pl. a Bándkúttelke: 1312: Bandkuthtelke, p. (Gy. 2: 59, Doboka vm.), Körösmonostora: 1332-5/PR.: Kewrsmonasterio, 1376: Keresmonostora, p. (KMHsz. 1: 165, Baranya vm.), Rackatelke: 1271: Rochkateluky, t. (Gy. 4: 287, Nógrád vm.), Sóspataktelke: 1320: Sospotokteleky (Gy. 3: 370, Kolozs vm.), Szamosfalva:1345: Samusfalua (Gy. 3: 370, Kolozs vm.), Zalatelke: 1310: Zalatheluke, p. (Cs. 3: 125, Zala vm.); ritkán pedig más típusú helyre utalnak: vö. pl. Bodróvölgytelke: 1332: Bodrouneulgteluke, t., p. (Gy. 3: 343, Kolozs vm.), Kiserdötelek: 1332: Kyserdeuteluk, t., p. (Gy. 3: 352, Kolozs vm.). E névstruktúra a kétrészes nevek 8\%-ában jelentkezik.

Általános földrajzi jellegre, a természeti környezetre utalnak viszont az alábbi településnevek (a kétrészes nevek 51\%-a): Hegyfalu: 1337: Hegfalu, Hygfalu (Cs. 2: 754, Vas vm.), Szegfalu: 1329: Zegfalw, p. (Cs. 3: 103, Zala vm.), Tófalu: 1272: Rovfolu [o: Tovfolu], t. (Gy. 2: 410, Fejér vm.), Tóslak: +1237/[1237-42]: Thovsloch (KMHsz. 1: 280, Borsod vm.), Völgyfalu: 1323: Weughfolu, v. (Cs. 2: 363, Valkó vm.) stb., ezek elötagjaként földrajzi köznév azonosítható. Az Ágtelek: 1270/1411: Ogteluk Ogthelek, v. (NÉMETH 1997: 19, Szabolcs vm.), Agyagtelek: 1288: Agyagthelek(Cs. 3: 218, Veszprém vm.), Körtvélyestelek: 1348: Kurtwelesteluk (NÉMETH 2008: 161, Szatmár vm.), Virágostelke: 1324: Vyragusteluky (Gy. 2: 443, Fejér vm.); Farkasfalva: 1334: Farkasfalua (KOCÁn 2017: 95, Ugocsa vm.), Ölyvesfalva: 1335: Wluesfalwa, p. (Cs. 3: 49, Zala vm.), Rigótelke: 1320: Rigotheleke, p. (Gy. 2: 85, Doboka vm.), Vadasfalva: 1280: Vadosfolua, t. (Cs. 3: 634, Sopron vm.) stb. nevekben pedig előtagként növénynévi, állatnévi, anyagnévi lexéma vagy annak képzős származéka áll.

2.3.2. A másodlagos keletkezésủ településnevek utótagjában minden esetben településnévi lexéma szerepel, a bővítményrészben pedig természeti nevet (víznevet, hegynevet stb., nagyon ritkán településnevet) ${ }^{3}$ vagy természeti környezetre utaló köznevet találunk.

\footnotetext{
${ }^{3}$ A településnevek ugyan nem tartoznak a természeti nevek közé, mégis itt említem ezeket, mert névrendszertani szempontból ide (is) jól illenek.
} 
A mai településnév-rendszerben gyakoriak az olyan névszerkezetek, amelyekben - a településnevek körében gyakori homonímiát megszüntetendő - az elötagban megnevezett hely (víz, hegy, erdő stb.) melletti fekvés tükröződik. A természeti nevet tartalmazó, a hely elhelyezkedésére utaló megkülönböztető előtagú településnevek a korai ómagyar korban azonban jóval ritkábban fordultak elő (a kétrészes neveknek csupán a 11\%-a mutat ilyen struktúrát). Ezek a településnevek a legtöbb esetben víz melletti elhelyezkedésre utalnak: vö. pl. Gyöngyöspüspöki: 1261/1271: Gunguspispuky (Gy. 3: 127, Heves vm.), Igantöszentgyörgy: 1347: Iga[n]tewscengurg (Gy. 3: 316, Keve vm.), Kebeleszentmárton: 1338: Kebeleyscenthmartun, p. (Cs. 3: 68, Zala vm.), Túrpásztó: 1281: Tuparstuha, v. (Cs. 1: 671, Külsö-Szolnok vm.), Túrterebes: 1321: Turterebes (KoCÁN 2017: 95, Ugocsa vm.) stb.; ritkábban pedig más típusú hely (erdő, hegy) melletti közelséget tükröznek: pl. Erdőszádkeszi: 1278/XVIII.: Erdizadkezi (KMHsz. 1: 92, Arad vm.); kivételesen másik település szomszédságát is jelölhetik: Egerszalók: 1328>1344: Egerzalouk, p. (Gy. 3: 133, Heves vm.), Szihalombuda: 1281/3124: Scenholmbuda (Gy. 3: 75, Heves vm.) stb.

Az általános földrajzi viszonyokra utaló másodlagos településnevek 30\%-os gyakorisággal fordulnak elő a korai ómagyar korban. Földrajzi köznévi alapszót találunk pl. a Mezösomlyó: 1270: Mezeusumlow (BorovszKY, Temes, 75), Mezöszentmárton: 1346/1347: Mezewzentmartun (Gy. 4: 520, Pest vm.), Ságizsidód: 1225: Sagisidoud, v. (Gy. 3: 240, Hont vm.) településnevekben; növénynévi alapszó szerepel pl. a Búzásbocsárd: 1332-5/PR.: Buzasbuchard Buzazbuchard (Gy. 2: 134, erdélyi Fehér vm.), Diósgyör: 1304: Gyous Geur, v. (KMHsz. 1: 83, Borsod vm.), Harasztigyarmat: 1290: Haraztigyormot, v. (Gy. 4: 246, Nógrád vm.), Somberény: 1193: Sumberhein (Cs. 2: 592, Somogy vm.), Szölösmegyer: +1252/[1270]: Sceuleus Meger, v. (Gy. 2: 608, Györ vm.) településnevekben; állatnévi lexémát találunk a következö helynevekben: vö. pl. Békásmegyer: 1287: Bekasmeger (Gy. 4: 658, Pilis vm.), Farkaskorhi: 1296/XV.: Forkoskorhy, p. (KMHsz. 1: 96, Borsod vm.); az ilyen szerkezetü településnevek előtagjában anyagnév is elöfordulhat: vö. pl. Homokkomár: 1293: Humukcamar (Cs. 3: 62, Zala vm.), Kökeszö: +1135/+1262/1566: Kukezu, pr. (Gy. 3: 207-208, Hont vm.) stb. A fenti példákból jól látható, hogy e közszók alapalakban és képzett formában egyaránt állhatnak a településnevek előtagjaként.

3. A természeti környezetre utaló településnevek strukturális jellemzőit, olykor keletkezéstörténeti folyamatait is vizsgálva a fentiekben igyekeztem bemutatni e névtípus prototipikus csoportjait, valamint próbáltam rávilágítani a kettős szemantikai tartalmú, pontosabban nem megítélhető (lokális vagy általános földrajzi viszonyokra utaló) kategóriákra is. A 4. ábra diagramja az e településnévtípusba tartozó két fó kategóriának a környezetre utaló közszói és tulajdonnévi összetevőit mutatja be szerkezeti formák szerint. 


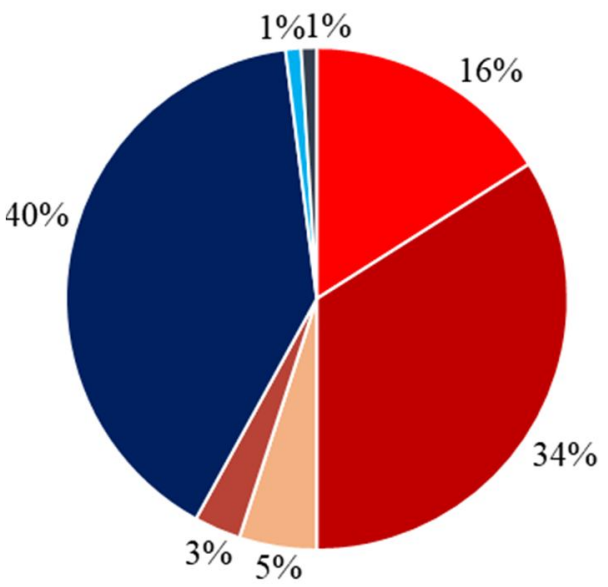

közszó utal a környezetre

- természeti kömyezetre utaló szó

- természeti kömyezetre utaló szó + helynévképző

- természeti környezetre utaló szó + földrajzi köznév

- természeti környezetre utaló szó + településnév

helynév utal a környezetre

- természeti név

- természeti név + földrajzi köznév

- természeti név + településnév

4. ábra. A természeti környezetre utaló településnevek szerkezeti típusai lexikális alkategóriák alapján

A fentiekből világosan látszik, hogy a korai ómagyar korban leggyakrabban az egyrészes formáns nélküli, illetve a képzőmorfémával alkotott, természeti viszonyokat tükröző településnevek fordulnak elö. Az ábra azt is jól mutatja, hogy a településnév-adásban a metonimikus névadás játszotta a meghatározó szerepet, a természeti viszonyokra utaló településnevek 56\%-a $(40 \%+16 \%)$ ily módon jött létre. A helynévképzővel való (morfematikus) névalkotás szintén jelentős számú településnevet eredményezett, a településnevek bő egyharmada (34\%-a) képzés útján keletkezett. A kétrészes településnevek száma azonban igen csekély: az összes névnek mindössze az egy tized részét teszi ki. Ezek között többnyire közszói előtagot $(5 \%+3 \%)$ tartalmazó névstruktúrák fordulnak elö. Másfelöl szemlélve azt látjuk, hogy a természeti környezetre utalás szerepe nagyobb részt (58\%) közszói elemekhez, kisebb részben pedig (42\%) tulajdonnévi értékü helynevekhez kötődik. E helynevek csaknem kétharmada víznév: e névcsoport az egész itt vizsgált névtípusnak az egy negyed részét teszi ki. Figyelemre méltó a névtípusban a földrajzi köznévi lexémák gyakorisága is, noha települést jelölö földrajzi köznevek csak a kétrészes nevekben, az összes név 6\%-ában szerepelnek. A nevek közel 40\%-ában található azonban valamely más helynévfajtára utaló földrajzi köznévi névelem: ezek magas aránya azt jelzi, hogy e szavak eredeti jelentése nem zavarja a befoglaló nevek településnévként való funkcionálását.

4. Az efféle vizsgálatok, illetve a névstruktúrák más szempontú (pl. az időbeli, térbeli viszonyokat érintő stb.) részletes és alapos tanulmányozása során pontosabb képet kaphatunk egyrészt nemcsak magukról a természeti viszonyokra utaló településnevekről, hanem a településnév-rendszer egészéről is, másrészt — mivel ez a névtípus mutatja a legszorosabb összefüggést a természeti nevekkel - a mikrotoponimákról is újabb ismereteket szerezhetünk. 


\section{Irodalom}

A. = Anjoukori okmánytár I-VI. Szerk. NAGY IMRE. Budapest, Magyar Tudományos Akadémia, 1878-1891. VII. Szerk. TASNÁDI NAGY GyUlA. Budapest, Magyar Tudományos Akadémia, 1920.

AOklt. = Anjou-kori oklevéltár. Documenta res hungaricas tempore regum andegavensium illustranta 1-. Szerk. KRISTÓ GYULA. Budapest-Szeged, Csongrád Megyei Levéltár-Szegedi Középkorász Mühely, 1990-. 27. Szerk. PITI FERENC. Budapest-Szeged, 2007.

ÁSz. = FEHÉRTÓI KATALIN 2004. Arpád-kori személynévtár. 1000-1301. Budapest, Akadémiai Kiadó.

BOROVSZKY SAMU 1898. Magyarország vármegyéi és városai. Vas vármegye. Budapest, Magyar Tudományos Akadémia.

BorovszKy SAmu é. n. Magyarország vármegyéi és városai. Pozsony vármegye. Budapest, Magyar Tudományos Akadémia.

BoROVSZKY SAMU é. n. Magyarország vármegyéi és városai. Somogy vármegye. Budapest, Magyar Tudományos Akadémia.

BorovszKy SAMU é. n. Magyarország vármegyéi és városai. Temes vármegye. Budapest, Magyar Tudományos Akadémia.

BoROvSZKY SAMU é. n. Magyarország vármegyéi és városai. Torontál vármegye. Budapest, Magyar Tudományos Akadémia.

BOROVSZKY SAMU é. n. Magyarország vármegyéi és városai. Zemplén vármegye. Budapest, Magyar Tudományos Akadémia.

Cs. $=$ CsÁNKI DEZSÖ 1890-1913. Magyarország történelmi földrajza a Hunyadiak korában I-III., V. Budapest, Magyar Tudományos Akadémia.

FNESz. = KISS LAJOS 1988. Földrajzi nevek etimológiai szótára I-II. Negyedik, bövített és javított kiadás. Budapest, Akadémiai Kiadó.

Gy. = GYÖRFFY GYÖRGY 1963-1998. Az Árpád-kori Magyarország történeti földrajza $I-I V$. Budapest, Akadémiai Kiadó.

HA. 1-4. = HOFFMANN ISTVÁN-RÁCZ ANITA-TÓTH VALÉRIA 1997, 1999, 2012, 2017. Helynévtörténeti adatok a korai ómagyar korból. 1. Abaúj-Csongrád vármegye. 2. Doboka-Györ vármegye. 3. Heves-Küküllö vármegye. 4. Liptó-Pilis vármegye. Debrecen, Debreceni Egyetemi Kiadó.

HofFMANn IstVÁn 1993. Helynevek nyelvi elemzése. A Debreceni Kossuth Lajos Tudományegyetem Magyar Nyelvtudományi Intézetének Kiadványai 61. Debrecen. Újraközlése: Budapest, Tinta Könyvkiadó, 2007.

HOFFMANN ISTVÁN-RÁCZ ANITA-TÓTH VALÉRIA 2018. Régi magyar helynévadás. A korai ómagyar kor helynevei mint a magyar nyelvtörténet forrásai. Budapest, Gondolat Kiadó.

KENYHERCZ RÓBERT é. n. A középkori Szepes vármegye helyneveinek adatbázisa. Debrecen. Kézirat. 
KMHsz. $=$ HofFMANN IsTVÁN szerk. 2005. Korai magyar helynévszótár 1000-1350. I. Abaúj-Csongrád vármegye. A Magyar Névarchívum Kiadványai 10. Debrecen, Debreceni Egyetem Magyar Nyelvtudományi Tanszéke.

KoCÁN BÉLA 2017. Helynévtörténeti vizsgálatok a régi Ugocsa megyében. A Magyar Névarchívum Kiadványai 45. Debrecen, Debreceni Egyetemi Kiadó.

KovÁCs Éva 2017. A természeti környezetre utaló településnevek. Magyar Nyelvjárások 54: 121-135.

KovÁCs Éva 2018. A Százdi alapitólevél mint helynévtörténeti forrás. A Magyar Névarchívum Kiadványai 48. Debrecen, Debreceni Egyetemi Kiadó.

MÁlyUSZ ElEMÉR 1922/2014. Turóc megye kialakulása. Budapest, Budavári Tudományos Társaság. Újraközlése: Historia Incognita III. sorozat. Máriabesnyő, Attraktor, 2014.

NÉMETH PÉTER 1997. A középkori Szabolcs megye települései. Nyíregyháza, Ethnica. NÉMETH PÉTER 2008. A középkori Szatmár megye települései a XV. század elejéig. A Nyíregyházi Jósa András Múzeum Kiadványai 60. Nyíregyháza.

RESZEGI KATALIN 2009. A jelentéshasadás mint helynévalkotási mód. Helynévtörténeti Tanulmányok 4: 35-45.

TÓTH VALÉRIA 2008. Településnevek változástipológiája. A Magyar Névarchívum Kiadványai 14. Debrecen, Debreceni Egyetem Magyar Nyelvtudományi Tanszéke.

Z. = NAGY IMRE-NAGY IVÁN-VÉGHELY DEZSÖ-KAMMERER ERNÖ-LUKCSICS PÁL szerk. 1871-1931. A zichi és vásonkeői gróf Zichy-család idősb ágának okmánytára I-XII. Pest, majd Budapest, Magyar Történelmi Társulat.

\section{Structural Issues in Settlement Names Referring to the Natural Environment}

In my paper I study the structural groups of an important name type in the Hungarian settlement name system, i.e., settlement names referring to the natural environment. I highlight what kind of semantic and lexical-morphological models characterize the particular name structures and what their frequency is. The typological descriptions differentiate between three larger structural types among toponyms: 1. single-component names without a formant, 2 . single-component names with topoformants, and 3. two-component toponyms formed by means of compounding.

Within the basic types of settlement names referring to the natural environment, more than half $(56 \%)$ of the name corpus is made up by single-component settlement names without a formant, while $34 \%$ of the names were created as single-component toponyms with formants; this means that the character of the name type is clearly defined by the single-component structure. The proportion of two-component settlement names referring to the natural environment is only $10 \%$. In terms of their lexical structure, the single-component denominations without a formant may be of four types, as these name formants may contain 1 . 
single-component toponyms (e.g., Tapolca settlement name $<$ Tapolca hydronym), 2. two-component toponyms (e.g., Kökényér settlement name $<$ Kökény-ér 'blackthorn/brook' hydronym), 3. a geographical common noun (e.g., Er settlement name < ér 'brook') or 4. other type of common nouns referring to the natural environment (e.g., Alma settlement name < alma 'apple' tree name).

The names in the second large structural group of settlement names referring to the natural environment, the single-component toponyms with formants, belong to practically two types of lexical subcategories. The topoformant may be attached to a geographical common noun base word (e.g., Erdöd < erdö 'forest' $+-d$ topoformant) or a common noun referring to the natural environment, primarily to plant and animal names (e.g., Somogy< som 'dogwood' + -gy suffix).

The third large structural group of settlement names of this name type are made up by two-component settlement names. The first name constituent of twocomponent settlement names may include a natural name (hydronym, oronym, etc.) or a common noun referring to the natural environment (geographical common noun or other type of lexeme, e.g., plant name, animal name, etc.), while in their second name constituent there is either a common noun meaning 'settlement' (e.g., Szamosfalva 'village/next to the river Szamos') or a settlement name (e.g., Kecskéskér 'settlement named Kér/abundant in goat'). Settlement names with such a structure, however, are very rare in the early Old Hungarian Era.

When studying this less researched name type in more detail and thoroughly, we may gain more precise insights into this group of settlement names expressing specific relationship and (as this name type shows the closest relationship with natural names) we may also gain new knowledge about microtoponyms. 